\title{
Social Entrepreneurs and Community Development. A Literature Analysis
}

\section{Portia Malunga}

\author{
Department of Entrepreneurship and Business Management \\ Faculty of Business, Cape Peninsula University of Technology, South Africa
} Email: malungaportia@gmail.com

\section{Chux Gervase Iwu}

Department of Entrepreneurship and Business Management Faculty of Business, Cape Peninsula University of Technology, South Africa Email: iwuc@cput.ac.za; chuxiwu@gmail.com

\author{
Victor Virimai Mugobo \\ Department of Retail Business Management \\ Faculty of Business, Cape Peninsula University of Technology, South Africa \\ Email:mugobov@cput.ac.za
}

\section{Doi:10.5901/mjss.2014.v5n16p18}

\section{Abstract}

What do social entrepreneurs do? Do they play any significant role in community development? Could they really play any meaningful roles in community development? These are some of the questions that were taken on in this paper which relied immensely on secondary data. To achieve a healthy infusion of the different misconceptions of the concept of social entrepreneurship, there was an unpacking of the terms social and entrepreneurship. What emerged was a finer articulation of a concept that counts on individuals or a group of them working together to address matters of significance to a set of people. Some examples of the good that social entrepreneurs can and have done are presented, while some of their challenges are highlighted. The paper concludes by recommending a further engagement of the subject in an empirical form to better ascertain their real impact. The paper also suggests an examination of the legislative frameworks that exist in other countries for the benefit of the South African government.

Keywords: Social Entrepreneurship, Social Change, Community Development, North Star Alliance, Wilderness Foundation, Treatment Action Campaign, Section 27, South Africa, Cape Town

\section{Introduction and Background}

There is no debate as to whether social entrepreneurs have a role to play in the development of any economy. The crux seems to be to what extent they add value to society.

Social entrepreneurship has emerged as a contemporary issue in the social arena. It is a concept well suited for this age (Dees, 2001:1). Dees also makes a call for entrepreneurial activities to spearhead the resolving of social issues; since many governmental and charitable efforts have failed to meet the existing social needs. Dees therefore makes a case for social entrepreneurs by highlighting that they fill the gap that has been left void by the ineffectiveness, inefficiency and the lack of sustainability from major institutions. While it may seem as though Dees has attached some nobility to the concept, Mair and Mati (2006:100) are also of the opinion that the concept catalyses social change and addresses important social needs in a way that is not dominated by direct financial benefit for an entrepreneur. This somewhat broadly indicates that social entrepreneurship signifies a business model for individuals and non-governmental organizations fulfilling social issues.

Scholars around the globe have become interested in the concept and have continuously provided fascinating case studies and promising conceptual approaches. However, Dees (2001) states that though the concept of social entrepreneurship is emerging as a popular issue, it has different meanings to different people. Light (2010:352) concurs with Dees by asserting that there is still controversy on what the concept actually means. Where and when it should be used is still confusing. Smith and Stevens (2010:575) seem to agree with Dees (2001) and Light (2010). It is the opinion 
of Smith and Stevens that while social entrepreneurship has captivated the interests of social researchers and community practitioners, the concept is still poorly defined and that its boundaries to other fields of study remain fuzzy. While to some this may appear to be a problem, it is a unique opportunity for researchers from different fields and disciplines, such as entrepreneurship, sociology and organizational theory, to challenge and rethink central concepts and assumptions (Mair \& Marti 2006:41).

We agree with the above. This is because over the years we have also become interested in the concept of social entrepreneurship due to its growing popularity among social researchers and community practitioners. These social researchers and community practitioners insist that social entrepreneurship is a tool for addressing social issues; thus prompting us to examine the famed attractiveness or otherwise of social entrepreneurs in terms of community development. We focus on Cape Town, South Africa.

We also take solace in Welsh's (2012: 273) counsel that as the process of social entrepreneurship gains popularity, there is a need to explore its complex and dynamic nature and its role in transforming communities. We acknowledge Bacq and Janssen's (2011:376) assertion that it is imperative to understand the nature of social entrepreneurship as the indiscriminate use of the term social entrepreneurship may undermine its significance and potential importance to those seeking to understand how societies change and progress. This paper will also evaluate the importance of impact measurement in order to legitimise a field which is still in its infant stages in South Africa.

Given the foregoing, the meaning of social entrepreneurship will now be discussed.

\section{What is Social Entrepreneurship?}

Many researchers have attempted to justify the significance of social entrepreneurs by focusing on "definitions, boundaries and goals (Perrini et al., 2010:515). However there is a shift towards focusing on the actual impact of social entrepreneurs, as the idea is to ascertain the contribution made by linking their activities to the social change claimed (Mair \& Martí 2006; Pärenson 2011; Nicholls 2009; Gilliss 2011; Bloom \& Chatterji 2009).

To understand social entrepreneurship there is a need to unpack the "social" element of the concept. Mari and Marti (2006:44) present the example of three successful cases of entrepreneurship around the globe which are essential for understanding the 'social' aspect in social entrepreneurship. These are the Grameen Bank in Bangladesh, the Aravind Eye Hospital in India and Sekem in Egypt. These social enterprises reveal a common feature: all three creatively combine resources-resources that often they themselves do not possess-to address a social problem and thereby alter existing social structures. The Grameen Bank, founded by Professor Muhammad Yunus in 1976, has changed the lives of millions by bringing financial services to the poor (Yunus, 1999:237). This example shows how social entrepreneurship addresses social problems, in this case poverty, as poor people cannot access loans in commercial banks. This brings a new equilibrium in the society when the poor are also able to access financial services.

After understanding the "social" in social entrepreneurship, it is essential to understand the term entrepreneurship. The term entrepreneurship originated in France as early as the 17th and 18th centuries (Dees, 2001). In agreement with Dees are Mugobo and Ukpere (2011:828) who point out that the word originated from the "French verb entreprendre and the German word unternehmen". They mention that the term was originally used "in the middle ages, implying a person who is active, who gets things done".

Entrepreneurship as a practice seems to also attract some degree of misunderstanding among researchers. In some cases, entrepreneurship is defined as the process of adding something new (creativity) and something different (innovation) for the purpose of creating wealth for the individual and adding value to the society (Kao, 1993:3), while in another instance, being an entrepreneur is linked to starting a business. This, according to Dees (2001:1) is very narrow for a concept which is significant and has evolved over the years. The perception of entrepreneurship as possessing economic benefits for an entrepreneur was recently contested by Korsgaard and Anderson (2011:135) who insist that economic growth is not the only relevant outcome of entrepreneurship. They argue that entrepreneurship is as social as it is economic. In fact Rai (2008:215) argues that entrepreneurship can be explained as a continuous innovative practice by an entrepreneur who works under hard conditions associated with uncertainty and high risks yet ensuring productivity in their ventures.

With respect to the link to innovation made by Kao (1993) above, Zampetakis and Moustakis (2006:415) further highlight that innovation may be viewed, as the ability to quickly recognise the relationship that might exist between an existing problem and a probable solution by identifying a solution which is unaccustomed or by using the resources available in an unusual manner to solve an existing problem. Therefore, innovation can be seen as an essential element of entrepreneurship. Leadbeater (1997:19) argues that there is a need to innovatively develop new forms of social capital through social entrepreneurs to empower disadvantaged people and encourage them to take greater responsibility for 
and over their lives. It is evident that Leadbeater concurs with Kao's view that entrepreneurship, regardless of its context, must include innovation and adding value to the society.

For the purpose of this paper, social entrepreneurship will be defined as the product of individuals, organizations, and networks that challenge conventional structures by addressing failures-and identifying new opportunities-in the institutional arrangements that currently cause the inadequate provision or unequal distribution of social and environmental goods (Nicholls, 2009:209). This definition is suitable as it acknowledges that social entrepreneurship can happen in any form be it for individuals, in organisations and within networks. For social entrepreneurship to be entrepreneurial; opportunity identification is paramount. Social entrepreneurship is therefore a significant tool in addressing social problems including unemployment, poverty, and education (Smith et al. 2008; Shaw \& Carter 2007; Peredo \& McLean, 2006). It is an innovative approach for dealing with complex social needs (Johnson, 2000:16).

Social entrepreneurship differs from business entrepreneurship. Social entrepreneurs operate in the community and are more concerned about social issues affecting the community than "profit making" as is common in business entrepreneurship (Kao, 1993). Madhuka (2006) points out that a business entrepreneur may create changes in the society, but that is not the primary purpose of starting the venture. Similarly, a social entrepreneur may generate profits, but that may not be the primary reason for starting the venture. Being 'profitable' helps self-sustainability of the venture, and also works as a mechanism for self-monitoring. Madhuka illustrates with Grameen Bank; Grameen's central focus is to help poor borrowers move out of poverty, not making money. Making profit is always recognised as a necessary condition for success to show that they are covering costs. The volume of profit is not important in Grameen in moneymaking sense, but important as an indicator of efficiency (Madhuka, 2006).

It is apparent that social entrepreneurs focus on innovation for the purposes of social change rather than the maximising of profits as the true reward to a social entrepreneur is not financial gain but social capital to influence change in the communities. Common across all definitions of social entrepreneurship which have been discussed hitherto is the underlying drive for social entrepreneurs to create social value, rather than personal and shareholder wealth.

Smith and Stevens (2010:578) recognise that placing social entrepreneurs into specific categories (typology) is a limitation as it narrows social entrepreneurship; however such typology is advantageous as it provides an important theoretical framework to the academic enquiry in the field of social entrepreneurship. To that end, the different types of social entrepreneurs will be discussed so as to provide a much enlarged understanding of the concept.

\section{Types of Social Entrepreneurs}

According to Smith and Stevens (2010:578), there are three types of social entrepreneurs. These include social bricoleur, social constructionist and social engineers. Social bricoleurs target the local social issues. They have first-hand experience with the problems which the community faces. The recognition of the problem is stimulated by their exposure to the community they reside in.

Social constructionists generally identify opportunities that others would not have yet identified to be an opportunity until their venture is successful and operational. Unlike social bricoleur their target is broader than the local community and their solutions can be used in various contexts. This then makes social constructionists to be resource dependent because the scalability of their mission depends on the resources they possess.

Social engineers on the other hand focus on large-scale issues with mass appeal that everyone is well aware of, like unemployment. They then create solutions that transform the entire existing system to deal with the issue.

\section{The Role of Social Entrepreneurs in Community Development}

Jafta (2013:1) explains that social entrepreneurship can help solve some of South Africa's developmental problems and address the lack of social cohesion. Jafta further highlights that social entrepreneurship is important because sources such as the National Planning Commission's Diagnostic Report of 2011, the Social Cohesion Summit Report (Department of Arts and Culture, 2012), as well as media reports and casual observations show that South Africa's developmental problems are beyond economics in nature as South Africa has one of the most unequal societies in the world. Community development requires the involvement of social entrepreneurs who are able to mobilize community resources for the purpose of attaining their social mission (Dhesi, 2010:705).

Cape Town commonly known as the mother city also has game changers. The Cape Town Carnival falls broadly within the definition of social entrepreneurship. The Cape Town Carnival is a glamorous celebration of African identity, diverse communities and cultures, and the transformative power of creativity. Among its many objectives, the carnival aims to provide opportunities for community participation in arts and culture and create a significant hub for the clothing, 
costume and set-building industries in the Western Cape. It also strives to create employment and training opportunities in costume, float design and production as well as large event logistics. All these it does through the celebration of the diversity - culture, language, colour, race, gender and sexual orientation - of South Africa. Away from the glitz and glamour of the Cape Town Carnival is the Green-pop. According to Watters et al (2012:1), Lauren and the co-founders of Green-pop are addressing the global deforestation problem and greening the 'unleafy' areas of the Cape while creating employment opportunities. Symphonia, a Cape Town social entrepreneur was recognized in the global Corporate Social Responsibility Award for its innovative leadership development programme where business leaders are partnered with school principals in co-learning and co-action partnership (Moily, 2012:1).

Mudluli (2010:1) discusses some other exceptional examples of social entrepreneurs in South Africa like Paul Matthew and Andrew Muir. Paul and Andrew's organisations were two of the recipients of the African Social Entrepreneur of the Year Awards at the World Economic Forum in Africa held in Ethiopia. Matthew is the director of North Star Alliance, an innovative public-private partnership that specialises in building sustainable roadside clinics to meet basic health needs. Muir is the executive director of the Wilderness Foundation, which was established in 1972. It integrates conservation programmes with social and educational programmes. It has trained thousands of young people in community leadership. They have also trained many others to become rangers in national parks.

Another success story within the realm of social entrepreneurship is The MySchool fundraising programme, which was established on 30 September 1997 by a Johannesburg based parent who wanted to help his child's school raise more funds in an easy and sustainable manner. Registered under the company name "Virtual Market Place", the MySchool programme soon became a popular fundraising tool in many schools. This project raises over R3.5 million for over 10000 schools and charitable organisations every month - that's over R36 million per year on average towards helping different South African communities (Virtual Market Place, nd).

As evident from the examples given above, social entrepreneurs play a crucial role in communities by creating new opportunities for local communities in terms of employment, income growth, enhanced provision of services, increase in local income retention and engaging the community in developmental programs.

Social entrepreneurs "make do" with what they have, they go "beyond the constraints of institutional rules and structures to fashion their own bundle of resources and repertoire of strategies and activities" (Di Domenico et al., 2010:698). Di Domenico and others affirm that; social entrepreneurs create social value for communities, as these developments might never have been attained by the governments or the private sector thus catalysing community development from nothing.

Thumbadoo and Wilson (2007:21) assert that social entrepreneurs "look at the world with new eyes"; where others see doom they see boom. For this reason the authors of this paper characterise social entrepreneurs metaphorically as architects of community development, because architects envision the erection of a spectacular structure where others might see a worthless piece of land.

Hervieux et al. (2010:57) give a good example of how social entrepreneurs better deal with social problems compared to other organisations. They assert that though it can be argued that commercial entrepreneurs also create social value through the creation of employment, the unique aspect about social entrepreneurs is that they "empower the marginalised population". Rather than just creating employment, they further create networks for the population to ensure that an individual permanently takes responsibility over their lives and fate (Hervieux et al., 2010:57). It is clear that the networks created by social entrepreneurs ensure more sustainable means of employment.

Furthermore, as social entrepreneurs take part in community development they tend to raise awareness of the problems faced by the community therefore creating networks for communities so that more people can participate in developing communities (Di Domenico et al., 2010:695; Farmer \& Kilpatrick 2009:1651). Di Domenico et al. (2010:699) elucidate that as social entrepreneurs strive to meet the needs of the community, they utilise resources that are usually considered to be useless to achieve their objectives. In addition, social entrepreneurs play a major role in dealing with social ills and have made significant contributions in community development. However the field of social entrepreneurship still faces profound challenges which make it difficult for social entrepreneurs to operate to their optimum level (Sud, VanSandt \& Baugous, 2009: 211). In its 2007/8 Annual Report, Community Development Resource Association (CDRA), James Taylor narrated the success story of Self-help Manenberg. This organisation was formed in an attempt to make psychological counselling and social services relevant to the lives and struggles of people living in Manenberg in the 90's. Manenberg was and is still regarded as one of the toughest communities in Cape Town. This community project turned Manenberg; previously viewed as a place of problem, into place of ability, human resources and community strength. However, according to James Taylor, intervention such as Self-help Manenberg was not enough for a number of reasons. Firstly, most of the interventions were funded by overseas organisations that had the challenge of accompanying their recipient organisations through their lengthy and often tortuous journeys of development 
towards independence and the ultimate prospect of interdependence. Secondly, there was also the question of impact. Jostling for funds meant that new business practices needed to be adopted resulting in very demanding bureaucratic accountability procedures. Therefore social entrepreneurs have to go great lengths to try and convincingly measure impact and prove what value they have added. In fact, many struggle to do this and as a result they question whether they will be able to do so in the long run.

Some challenges faced by social entrepreneurs will now be discussed.

\section{Problems Faced by Social Entrepreneurs}

Although there are success stories in Cape Town for social entrepreneurs, yet there are some barriers which still hinder social entrepreneurs from reaching their full potential. These include proper legal framework, poor business models, premature scaling, and lack of sustainability and so on.

Legal framework

Watters et al. (2012) found that South Africa has no legislative framework to deal with social enterprises. They essentially regard social entrepreneurs as a hybrid of social development and enterprise.

Watters et al's claim that South Africa has no legislative framework for social entrepreneurs stems from a 2009 visit undertaken by high level South African government officials to Belgium and the UK to explore legislative and other supportive frameworks used in these countries. The visit, sponsored by the International Labour Organisation (ILO), aimed at developing an understanding of Community Interest Companies and included meetings with the Office of the Third Sector and the Charity Commission in the United Kingdom. Sadly, Watters and his colleagues lamented that nothing meaningful has come out of that visit. This can be interpreted to mean that there has been no similar development in South Africa.

As a result of the lack of legislative frameworks for hybrid social entrepreneurs; most hybrids are forced to register as non-profit organisations and this hinders their operations. This limits the extent to which they can generate income while others resort to registering as for-profit organisations which in turn would remove their ability to have tax benefits. Due to the lack of legislative frameworks, hybrid social entrepreneurs "do not find the kind of support they need to blend socially and attain their financial objectives" (Dees, 2007:28).

Poor business models

Mehta and Ashok (2012) state that while microfinance spurs the initial growth of social entrepreneurs, there is still a challenge in finding the right business model for impact in sectors such as healthcare and education. One should however not ignore the presence of Treatment Action Campaign (TAC) and Section 27. While these non-governmental organisations advocate for cheaper access to anti-retroviral (in the case of TAC) and better equipped schools (in the case of Section 27), they constantly battle with both government and business regarding their objectives. The real issue here is quality, as there are enough low-cost options available today. For instance, government schools and hospitals provide accessibility and affordability but lack quality. At the 'low cost' we have in mind, quality may not come easily in these sectors. There is therefore the need for social entrepreneurs to re-define the current models which focus on merely providing services to providing better quality as there are enough low cost solutions.

Lack of sustainability

Though social entrepreneurs are viewed as the answer to sustainable solutions, in practise this is a major issue of concern as some social entrepreneurs are unable to create sustainable ideas. It is better to have an idea that can be replicated and sustained as it enforces more impact; than to have a single venture (Gilliss, 2011:256).

Premature scaling-up

Most social entrepreneurs make the mistake of expanding their social venture before they are properly established (Economic Times, nd). For this reason such social entrepreneurs fail to handle the increased scope of challenges that the community encounters, thus failing to meet the expectations of the community and other stakeholders.

\section{Social Impact Assessment of Social Entrepreneurs}

Social impact assessment is viewed as the "research and development arm of community development initiatives" (Madan, 2007:2) as it can be utilised as a feedback mechanism to all stakeholders. With time as the social entrepreneur makes more impact in the community, they are able to catalyse change in government policies; hence this exercise is critical to show the contribution of social entrepreneurs to stakeholders (Clark \& Brennan, 2012:26). Social impact assessment is defined as the process which results in finding how much one particular social problem has been relieved by the activities of one particular organisation (Pärenson, 2011:40). Social impact assessment is therefore essential so as 
to understand the perceived impact of social entrepreneurship.

Social entrepreneurs face an immense challenge in measuring social impact. This problem plagues the NGOs, government and development agencies around the world. When social entrepreneurs are able to demonstrate their social impact, it will provide credibility to the sector, and this will provide access to more work, more finance and more support, encouraging an upward spiral of success (Shah 2003:10-11). The Centre for the Advancement of Social Entrepreneurship (2008:8) concurs with Shah's view by acknowledging that the current success stories while powerful and moving, lack hard data or proven measures of success. Otherwise, this could look like a field with lots of little ventures that are admirable but almost never come close to the espoused goal of widespread, lasting impact, and that never match up to the problems they are designed to solve.

Much research has focused on the case studies or claimed success stories; however there is still room for more aggressive methods to legitimise and promote the field of social entrepreneurship (Pärenson 2011:40; Eva et al. 2013:105). Given the infancy of social entrepreneurship in South Arica social impact measurement is of important value so as to highlight the significance of the role(s) played by social entrepreneurs in terms of community development. Thus instead of interrogating the legitimacy of social entrepreneurs by evaluating the definitional issues or organisational context, this discussion will centre on social impact assessment as a pivotal issue in legitimising social entrepreneurship. Although social impact evaluation appears to be rational, yet researchers contend that it is challenging to measure social impact. Amm (2009:7) outlines that social impact assessment is challenging as there are no guidelines or rather regulatory instructions to conduct the process. Moreover Mair and Martí (2006:42) maintain that social impact assessment is challenging as it is difficult to quantify social contributions. The fact that social entrepreneurs have a social purpose makes it challenging to assess their social value unlike commercial entrepreneurs who rely on "tangible and quantifiable measures" (Pärenson 2011:45).

Despite the immense challenges, social impact assessment is not impossible (Madan 2007:2). The benefit of this exercise lies in that it makes the social entrepreneurs operations more transparent to different stakeholders therefore encouraging more funding and more people to engage with SEs as they are aware of their contributions to the society (Gilliss, 2011:256). Furthermore transparency improves their relations with the community as they would be aware of how genuine the social entrepreneurs' social mission is (Madan, 2007:2).

The benefits of social impact assessment go beyond funding due to transparency as it enables social entrepreneurs to utilise the outcomes of the report in their strategic planning to act as a feedback mechanism (Madan, 2007:2). It also enables better communication with relevant stakeholders on the specific impact obtained by social entrepreneurs.

\section{Conclusion and Implications}

There is no doubt, given the review espoused in this paper, that social entrepreneurs have an important role to play in community development. They motivate change in communities by creating a new equilibrium in the communities and affecting many people through innovative ideas therefore addressing social issues. They are able to identify opportunities and devise ways of taking advantage of these opportunities. Despite the growing popularity of the concept, the field of social entrepreneurship is still fuzzy. Attempting to uncover a universal definition of the concept or to clarify social entrepreneurial activities; is not sufficient to legitimise this emerging field. Undertaking social impact assessment might be challenging; however it is crucial as it brings to the fore the actual role played by social entrepreneurs in communities thus legitimising their operations.

Cape Town is still faced with many problems in the health, education, and housing sectors. Overcoming the problems may appear as a complex situation but for social entrepreneurs these are all opportunities where they can foster change. Although there are some examples illustrated in the paper about South African social entrepreneurs and more specifically Cape Town, yet there is a need to create more awareness about social entrepreneurship so that more social entrepreneurs can be found and supported to promote social change in the country as a whole. Beyond this, there is also the need for immense government and private sector support for social entrepreneurs. In fact, Jafta (2013) calls for a concerted public and private sector partnership in support of social entrepreneurs. Jafta insists that social entrepreneurs are a means of bridging the gap between the 'formal' world of governments and corporations, and the 'informal' world of community-based organisations and the voluntary sector. What this means therefore is that it is essential for businesses, government and social entrepreneurs to work together in addressing social and environmental challenges as this enables them to pull together complimentary resources that can promote sustainable development (Yakovleva \& Alabaster, 2004:83). Cross-sector partnerships facilitate the dealing of social ills in a better way. Failure to do this, according to Gomez-Jauregi (2004: 42), would result in the duplication of services delivered. 
When businesses work together with social entrepreneurs, they both achieve mutual benefits; these include sharing of knowledge, reputation, market access and so on (Dahan et al., 2010:331). Dahan et al. illustrate the role played by a business in advancing a social entrepreneur's goals. A multinational water distribution company and a social entrepreneur worked together in making an irrigation scheme in Latin America successful. The company provided the technology required for irrigation and the NGOs educated the farmers on the new technology available for irrigation. This resulted in $88 \%$ of the rural population engaging in commercial farming. We argue in this paper that without such a partnership such lofty results would not have been possible. This is a good example that both business and the South African government can emulate. Hopefully, the South African government can desist from viewing social entrepreneurs' operations as risky and dubious endeavours (Urban, 2008: 347).

The main advantage of a partnership between social entrepreneurs and businesses is in the pooling together of the needed resources which would lead to the development of a broader scope to be attained by the social entrepreneur (Yunus et al. 2010:315). This will no doubt strengthen the social entrepreneurs' capacity to liaise between government (and or business) and communities. Acting as go-between for the government and (or business) and communities will help in advancing the needs of the communities concerned; thus government and (or business) needs to provide social entrepreneurs with the requisite funding, training support, and infrastructure. Given that the main stakeholders for social entrepreneurs are the community members, we urge both business and government in South Africa to step up their support for social entrepreneurs because as our analysis has shown, social entrepreneurs can truly add value to society in many ways.

\section{Recommendations for further Engagement of the Subject}

Two major recommendations emerge from this analysis. First, we suggest an empirical investigation of the impact of social entrepreneurs in community development to ascertain their real impact. This should provide the necessary arsenal for considerations of funding and other support that social entrepreneurs may need. Another recommendation would be to examine the legislative frameworks prevalent in other countries in order to suggest which model the South African government can adopt.

\section{References}

Alana, R., Hartwig, K. \& Merson, M. (2008). Government - NGO collaboration and sustainability of orphans and vulnerable children projects in southern Africa, Evaluation and Program Planning, 31, pp.51-60.

Amm, K. (2009). Social enterprises, social value and job creation in Cape Town. An unpublished Master's thesis. Nelson Mandela Metropolitan University, South Africa.

Bacq, S. \& Janssen, F. (2011). The multiple faces of social entrepreneurship: A review of definitional issues based on geographical and thematic criteria, Entrepreneurship \& Regional Development, 23(5-6), pp.373-403. Available at: http://www.tandfonline.com /doi/abs/10.1080/08985626.2011.577242 [Accessed May 31, 2013].

Bloom, P.N. \& Chatterii, A.K. (2009). Scaling social entrepreneurial impact, California Management Review, 51(3), pp.114-133. Available at: http://www.jstor.org/stable/info/10.2307/41166496.

CDRA, 2007/2008 Annual Report. P.3.

Clark, C., \& Brennan, L. (2012). Entrepreneurship with social value: A conceptual model for performance measurement, Academy of Entrepreneurship Journal, 18(2), pp.19-39.

Dahan, N.M., Doh, J.P., Oetzel, J., \& Yaziji, M. (2010) Corporate-NGO collaboration: co-creating new business models for developing markets, Long Range Planning, 43, pp.326-42.

Dees, J.G. (2001). The meanings of 'social entrepreneurship, working paper. Stanford University: Stanford, CA.

Dees, J. G. (2007b). Taking social entrepreneurship seriously, Society, 44(3), pp.24-31. doi:10.1007/BF02819936

Dhesi, A. S. (2010). Diaspora, social entrepreneurs and community development, International Journal of Social Economics, 37(9), 703-716. doi:10.1108/03068291011062498

Di Domenico, M., Haugh, H., \& Tracey, P. (2010). Social bricolage: Theorizing social value creation in social enterprises, Entrepreneurship Theory and Practice, 34(4), 681-703. doi:10.1111/j.1540-6520.2010.00370.

Economic Times. (nd). Power of Ideas 2012: Five challenges for social entrepreneurs willing to create impact today - Economic Times. Retrieved from http://articles.economictimes.indiatimes.com/2012-09-21/news/34002453_1_social-enterprises-socialentrepreneurs-impact

Eva, A.A., Judith, L. \& Spiess-knafl, W. (2013). Disentangling gut feeling : Assessing the integrity of social entrepreneurs, Voluntas, 24, pp.93-124.

Farmer, J. and Kilpatrick, S. (2009). Are rural health professionals also social entrepreneurs?, Social Science \& Medicine, 69(11), pp.1651-1658. Available at: http://www.sciencedirect.com/science/article/pii/S0277953609005814 [Accessed October 21, 2013].

Gilliss, C.L., (2011). The nurse as social entrepreneur: Revisiting our roots and raising our voices, Nursing Outlook, 59(5), pp.256-257. 
Available at: http://www.sciencedirect.com/science/article/pii/S0029655411002533 [Accessed October 21, 2013].

Gomez-Jauregui, J. (2004). The feasibility of government partnerships with NGOs, Reproductive Health Matters, 12(24), pp.42-55.

Hervieux, C., Gedajlovic, E., \& Turcotte, M.-F. B. (2010). The legitimization of social entrepreneurship, Journal of Enterprising Communities: People and Places in the Global Economy, 4(1), pp.37-67. doi:10.1108/17506201011029500

Jafta, R . (2013). Social entrepreneurship can boost development in SA. http://blogs.sun.ac.za/news/2013/02/07/socialentrepreneurship-can-boost-development-in-sa/(12/12/2012)

Kao, R.W.Y. (1993). Defining entrepreneurship: Past, present and?, Creativity and Innovation Management, 2(1), Oxford: Blackwell.

Kihl, L. A., Tainsky, S., Babiak, K., \& Bang, H. (2014). Evaluation of a cross-sector community initiative partnership: Delivering a local sport program. Evaluation and Program Planning.

Korsgaard, S., \& Anderson, A.R. (2011). Enacting entrepreneurship as social value creation. International Small Business Journal, 29(2), pp 135-151.

Leadbeater, C. (1997). The rise of the social entrepreneur, Demos, London.

Light, P.C. (2010). The search for social entrepreneurship, International Entrepreneurship and Management Journal, 6(3), pp.351-355. Available at: http:/link.springer.com/10.1007/s11365-010-0137-0 [Accessed October 21, 2013].

Madan, R. (2007). Demystifying outcome measurement in community development. Joint Center for Housing Studies of Harvard University; NeighborWorks America.

Madhukar. (2006). Social vs. business entrepreneurship. http://inspired-pragmatism.blogspot.com/2006/09/social-vs-businessentrepreneurship.html [Accessed January 4, 2013]

Mair, J., \& Marti, I. (2006). Social entrepreneurship research: A source of explanation, prediction and delight, Journal of World Business, $41, \mathrm{pp} .36-44$.

Mdluli. A. (2012). Two South Africans take African social entrepreneur prizes. http://www.iol.co.za/business/business-news/two-southafricans-take-african-social-entrepreneur-prizes-1.1318542\#.UUIn4R11rpg (18/12/2013)

Mehta,V \& Ashok, A. (2012). Power of Ideas 2012: Five challenges for social entrepreneurs willing to create impact today. http://articles.economictimes.indiatimes.com/2012-09-21/news/34002453_1_social-enterprises-social-entrepreneurs-impact (20/12/2012)

Moily, T. (2012). Cape Town social entrepreneur wins international CSR award. http://leadsa.co.za/?p=7732 [Accessed January 16, 2013]

Mugobo, V. V., \& Ukpere, W. I. (2012). Rural entrepreneurship in the Western Cape: Challenges and opportunities. African Journal of Business Management, 6(3), pp. 827-836.

Nicholls, A. (2009). Learning to walk: Social entrepreneurship-A research review. Innovations: Special Edition Social Entrepreneurship, pp.209-222.

Pärenson, T., (2011). The criteria for a solid impact evaluation in social entrepreneurship, Society and Business Review, 6(1), pp.39-48. Available at: http://www.emeraldinsight.com/10.1108/17465681111105823 [Accessed June 16, 2013].

Peredo, A.M. \& McLean, M. (2006). Social entrepreneurship: A critical review of the concept, Journal of World Business, 41(1), pp.5665. Available at: http://linkinghub.elsevier.com/retrieve/pii/S1090951605000751 [Accessed May 21, 2013].

Perrini, F., Vurro, C. \& Costanzo, L.A., (2010). A process-based view of social entrepreneurship: From opportunity identification to scaling-up social change in the case of San Patrignano, Entrepreneurship \& Regional Development, 22(6), pp.515-534. Available at: http://www.tandfonline.com/doi/abs/10.1080/08985626.2010.488402 [Accessed May 31, 2013].

Rai, S. K. (2008). Indian entrepreneurs: An empirical investigation of entrepreneur's age and firm entry, type of ownership and risk behavior. Journal of Services Research, 8(1), pp.213-228.

Shaw, E., \& Carter, S. (2007). Social entrepreneurship: Theoretical antecedents and empirical analysis of entrepreneurial processes and outcomes, Journal of Small Business and Enterprise Development, 14(3), pp.418-434. doi:10.1108/14626000710773529

Smith, B. R., \& Stevens, C. E. (2010). Different types of social entrepreneurship: The role of geography and embeddedness on the measurement and scaling of social value, Entrepreneurship \& Regional Development, 22(6), pp. 575-598. doi:10.1080/08985626.2010.488405

Thumbadoo, B \& Wilson, G. (2007). From dust to diamonds. Johannesburg: Gordon Institute of Business Science.

Urban, B., (2008). Social entrepreneurship in South Africa skills, International Journal of Entrepreneurial Behaviour \& Research, 14(5), pp.346-363.

Sud, M., VanSandt, C. V., \& Baugous, A. M. (2009). Social entrepreneurship: the role of institutions. Journal of Business Ethics, 85(1), pp.201-216.

Virtual Market Place, nd. http://www.myschool.co.za/about-myschool/our-history. [Accessed April 2, 2014].

Watters, K, Willington, L, Shutte, T \& Kruh, R. (2012). Social Entrepreneurship - individuals with vision hold unlimited potential to alleviate poverty: The UnLtd South Africa model. http://www.carnegie3.org.za/docs/papers/290_Watters_social $\% 20$ entrepreunership $\% 20 \% 20$ individuals $\% 20$ with $\% 20$ vision $\% 20$ hold $\% 20$ unlimited\%20potential\%20to\%20alleviate $\% 20$ poverty.p df $(10 / 01 / 2013)$

Welsh, D.H.B. (2012). The evolution of social entrepreneurship: what have we learned? Journal of Technology Management in China, 7(3), pp.270-290. Available at: http://www.emeraldinsight.com/10.1108/17468771311325176 [Accessed June 18, 2013].

Yakovleva, N. \& Alabaster, T. (2004). Tri-sector partnership for community development in mining : a case study of the SAPI Foundation and Target Fund in the Republic of Sakha ( Yakutia ), Resources Policy, 29(2003), pp.83-98.

Yunus, M. (1999). Banker to the poor: Microlending and the battle against world poverty. New York: Public Affairs 
Yunus, M., Moingeon, B. \& Lehmann-ortega, L. (2010). Building social business models : Lessons from the Grameen Experience, Long Range Planning, 43(2-3), pp.308-325. Available at: http://dx.doi.org/10.1016/j.Irp.2009.12.005.

Zampetakis, L. A. \& Moustakis, V., (2006). Linking creativity with entrepreneurial intentions: A structural approach, The International Entrepreneurship and Management Journal, 2(3), pp.413-428. Available at: http://link.springer.com/10.1007/s11365-006-0006-z [Accessed May 29, 2013]. 